\title{
An online international pharmacy summer course during the COVID-19 pandemic
}

\author{
Rory E. Kim ${ }^{1}$ (D), Noam Morningstar-Kywi ${ }^{1,2}$ (D), Rebecca M. Romero², Karen M. Chan ${ }^{1}$, Lilit Gabrielyan ${ }^{1}$, \\ Yasi Mojab¹,2 (D), Sanjana S Parikh², Lindsay Nokes³, Terrence F. Graham ${ }^{3}$, lan S. Haworth ${ }^{2}$ (D) \\ ${ }^{1}$ Titus Family Department of Clinical Pharmacy \\ 2Department of Pharmacology and Pharmaceutical Sciences \\ ${ }^{3}$ Office of Global Initiatives, School of Pharmacy, University of Southern California, USA.
}

\author{
Keywords \\ Diabetes \\ Drug-Drug Interactions \\ International \\ Online Education \\ Undergraduate

\section{Correspondence} \\ lan S Haworth \\ Department of Pharmacology and \\ Pharmaceutical Sciences \\ School of Pharmacy \\ University of Southern California \\ 1985 Zonal Avenue \\ Los Angeles \\ CA 90089, USA \\ ihaworth@usc.edu
}

\begin{abstract}
The University of Southern California School of Pharmacy has offered a residential summer course for international undergraduate pharmacy students for many years, with a focus on clinical therapeutics. In 2020, the COVID-19 pandemic made it impossible to offer the on-campus course. After some discussion, the course was moved online, with the goals of maintaining links with international partners and providing students with a virtual study abroad experience. This article describes the planning and implementation of this course, which was held for two weeks in July 2020 for 19 students from South Korea, Taiwan and Saudi Arabia. The course included an integrated science and clinical approach to diabetes and drug-drug interactions. The facilitation of active learning and problem-solving in transnational student groups through Zoom meetings are described. A post-course survey of students provided positive feedback on the content and online delivery of the course.
\end{abstract}

\section{Introduction}

The experience of studying overseas is often one of the more memorable experiences of an undergraduate education. Exposure to a new environment can have lasting effects on personal and professional development (Ruth et al., 2018; Vanden Berg \& Schwander, 2019). This experience may increase the probability of a student moving overseas to pursue advanced degrees (Kato \& Suzuki, 2018) or may introduce students to new perspectives (De Sandes-Guimaraes et al., 2019), in addition to improving employability (Petzold, 2017). It is also likely that these opportunities will be enhanced by networking among students and faculty during an overseas educational experience. The value to universities of study-abroad programmes lies in internationalisation of education (Take \& Shoraku, 2017) and research collaboration (Giedt et al., 2015). Faculty motivation and job satisfaction may also be influenced by transnational teaching (Toohey et al., 2017).

For all of these reasons, University of Southern California (USC) School of Pharmacy has held a residential international student summer programme (ISSP) for undergraduate pharmacy students for many years (USC ISSP, 2020). The academic part of the programme has featured a mix of clinical sessions on drug information, healthcare delivery and patient cases, and scientific sessions on therapeutic mechanisms and drug design 
(Sutch et al., 2011, Romero et al., 2020). A combination of clinical and scientific material has always been a central element of the course.

In the early months of 2020, the developing COVID-19 pandemic forced consideration of the feasibility and safety of offering the residential summer programme. By early April, it was clear that the programme could not be held as planned. At this time, the decision was made to explore an online version, as a way to maintain relationships with university partners and provide students with the academic components of the usual on-campus experience. Several faculty participants have had experience in online education (El-Magboub et al., 2016), and active (problem-based) learning (Romero et al., 2010), which provided confidence that the new online course would be effective. This article describes the planning and implementation of this course, which was held from 6th-17th July, 2020

\section{Description of the Course}

\section{Course Design}

An overview of the course schedule is shown in Table I. Days 1 to 5 (Week 1: 6th to 10th July) and days 6 to 10 (Week 2: 13th to 17th July) were formal teaching sessions of a total of about four hours each. On most days this included 1.5 hours of clinical content, 1.5 hours of science content, and a final hour of group discussion. Each session was taught by a primary lecturer, with the assistance of at least four facilitators. Day 0 was used for general orientation and testing of technical issues, including hardware connections and resources required for the use of software in the course. Days 5 and 10 (the last day of each week) were used to diversify the course content through inclusion of two invited speakers to illustrate different career paths in pharmacy, and to allow assessment of student learning.

\section{Course content}

The course was focused on diabetes based on the personal expertise of the instructors, the potential to discuss pharmacological mechanisms and drug delivery from clinical and scientific perspectives, and the ability to integrate the effects of socioeconomic and demographic factors on outcomes into the course.

The course content in Week 1 covered diabetes pathophysiology, pharmacology and therapy. Week 2 broadly maintained the diabetes theme, but with a focus on drug-drug interactions (DDIs). The primary goal in delivering this material was to establish connections between scientific principles and clinical practice. Most days had a science and a clinical session, with the order of the sessions varied based on the content. In integrating the material, some separation was maintained in its delivery, but kept close correspondence between lectures to ensure alignment of content and reinforcement of material.

Table I: Daily course schedule showing clinical (CL) and science (SC) sessions

\begin{tabular}{|c|c|c|}
\hline Day & Session 1 & Session 2 \\
\hline $0^{*}$ & $\begin{array}{l}\text { General Introduction, } \\
\text { Introduction to the Course }\end{array}$ & Technical Check-up \\
\hline 1 & $\begin{array}{l}\text { CL1: Healthcare Delivery in the } \\
\text { United States and Worldwide }\end{array}$ & $\begin{array}{l}\text { SC1: Overview of Drug Delivery } \\
\left(\mathrm{ADME}^{\dagger}\right)\end{array}$ \\
\hline 2 & $\begin{array}{l}\text { CL2: Diabetes Pathophysiology } \\
\text { \& Treatment Guidelines }\end{array}$ & $\begin{array}{l}\text { SC2: Medicinal Chemistry of } \\
\text { Antidiabetic Agents }\end{array}$ \\
\hline 3 & $\begin{array}{l}\text { SC3: Mechanisms of Action of } \\
\text { Antidiabetic Agents }\end{array}$ & $\begin{array}{l}\text { CL3: Clinical Use of Oral } \\
\text { Anti-Diabetes Medications }\end{array}$ \\
\hline 4 & $\begin{array}{l}\text { SC4: Insulin Structure and } \\
\text { Pharmacokinetics }\end{array}$ & $\begin{array}{l}\text { CL4: Clinical Use of Injectable } \\
\text { Antidiabetic Agents and Insulin }\end{array}$ \\
\hline 5 & $\begin{array}{l}\text { Guest Speaker (Academic and } \\
\text { Clinical Pharmacy) }\end{array}$ & $\begin{array}{l}\text { Q \& A Session (Clinical and } \\
\text { Science Questions in Kahoot!) }\end{array}$ \\
\hline 6 & $\begin{array}{l}\text { SC5: Mechanisms of Drug-Drug } \\
\text { Interactions }\end{array}$ & $\begin{array}{l}\text { CL5: Clinical Assessment and } \\
\text { Management of Drug-Drug } \\
\text { Interactions }\end{array}$ \\
\hline 7 & $\begin{array}{l}\text { SC6: Chemiinformatics, } \\
\text { Molecular Graphics }\end{array}$ & $\begin{array}{l}\text { SC7: Molecular Docking, ADMET } \\
\text { Predictor }\end{array}$ \\
\hline 8 & $\begin{array}{l}\text { CL6: Cardiovascular Outcomes } \\
\text { Trials in Type } 2 \text { Diabetes }\end{array}$ & $\begin{array}{l}\text { CL7: Therapeutic Management } \\
\text { of Smoking Cessation }\end{array}$ \\
\hline 9 & $\begin{array}{l}\text { SC8: GastroPlus: Prediction of } \\
\text { Pharmacokinetics }\end{array}$ & $\begin{array}{l}\text { CL8: Clinical Management of } \\
\text { Severe Insulin Resistance }\end{array}$ \\
\hline 10 & $\begin{array}{l}\text { Guest Speaker (Pharmaceutical } \\
\text { Sciences in Industry) }\end{array}$ & $\begin{array}{l}\text { Group Presentations: Findings } \\
\text { on Case Reports, Certificate } \\
\text { Presentation }\end{array}$ \\
\hline
\end{tabular}

* Orientation day

${ }^{+}$ADME: absorption, distribution, metabolism, elimination

In Week 1 (Table I), Day 1 was used as an introductory day to allow relationships to be built among the students through discussion of the different factors that influence pharmacy practice and education in their respective countries. On Day 2, the pathophysiology of diabetes was introduced to provide the basis for potential therapeutic interventions, which were then discussed at the molecular level in back-to-back science sessions on Day 2 and 3. This was followed by a clinical session on appropriate use of these agents on Day 3. On Day 4, structural modifications of insulin that lead to changes in pharmacokinetics were discussed, followed by an explanation of why the different forms of insulin are important clinically.

In Week 2, Day 6 was devoted to discussion of the scientific basis, clinical importance, and overall manage- 


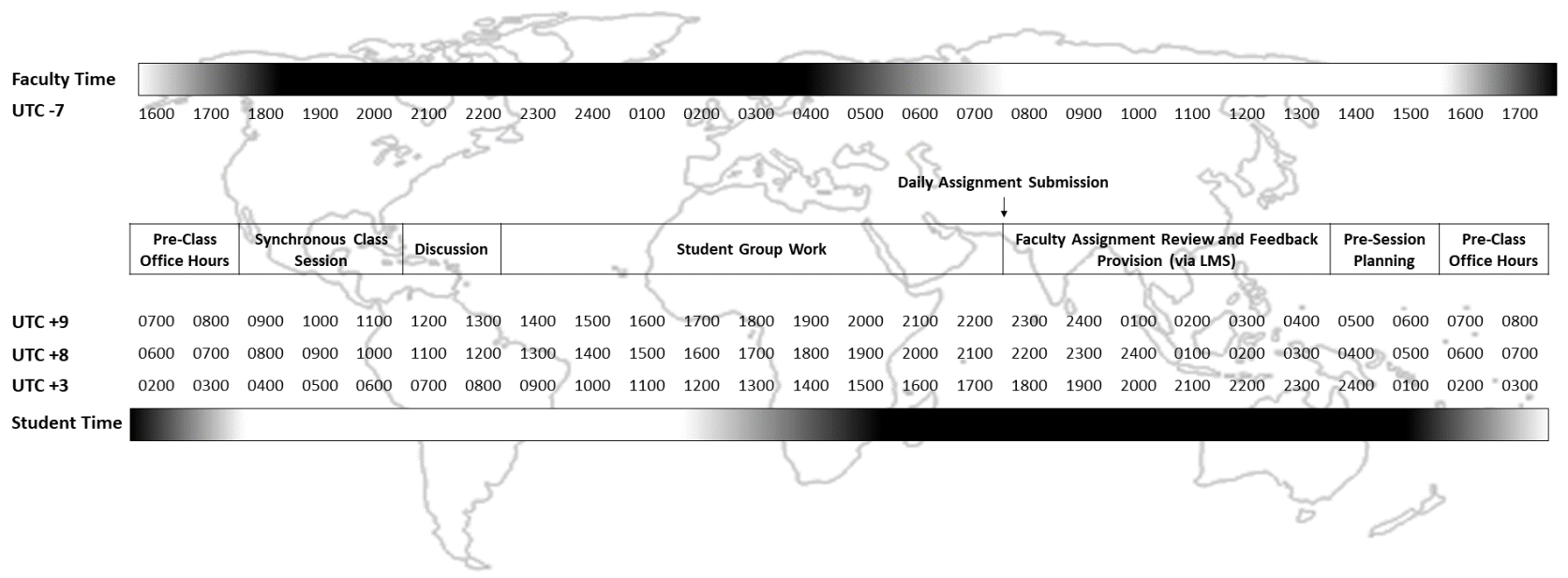

Figure A: Depiction of the timeline of a single course day, beginning with pre-class office hours

Faculty time (USA Pacific Daylight Time, UTC-7) is shown above the timeline, and student times (South Korea UTC+9, Taiwan UTC+8, Saudi Arabia UTC+3) are below. Light and dark shading indicate approximate daytime and nighttime for faculty and students, respectively. The blocks in the centre of the figure indicate joint student-faculty, student-only and faculty-only activities. Pre-class office hours at the right side of the timeline indicate the beginning of the next day.

ment of DDIs. Day 7 was used for a full day of teaching of computational methods for evaluation of protein-drug interactions and prediction of physicochemical, metabolic and transport properties of drugs, as described in detail elsewhere (Sutch et al., 2011; Romero et al., 2020). A key element in this work was utilisation of ADMET Predictor (Simulations Plus, 2020a) as a basis for collection of data to be used in project 2, as described below. Day 8 was similarly used for a full day discussion of management of cardiovascular risk factors in diabetes, including smoking cessation. Allowing a full three-hour session for the topics on Day 7 and 8 was more conducive to learning. Day 9 was used to connect the scientific and clinical material through prediction of pharmacokinetics in the context of DDIs in GastroPlus (Simulations Plus, 2020b) and through a complex case study of a patient on multiple medications with potential DDIs.

\section{Course projects}

Two team-based projects in Week 1 and 2, respectively, were used to provide coherent links among the lectures and discussions above. These projects also required the groups to work on the material outside of the class. As shown in Figure $A$, the students received the synchronous sessions in the morning (UTC +3 in Saudi Arabia, UTC +8 in Taiwan, and UTC +9 in South Korea; student local time), and then had the afternoon to work on the project and submit material. This allowed the course faculty to review these submissions and provide feedback before the next session (UTC -7 in Los Angeles; faculty local time). In this way, the instructors were able to take advantage of the time zone differences between faculty and students.

Table II: Design of Project 1 - Pharmacology and therapeutic use of anti-diabetes agents

\begin{tabular}{|c|c|c|}
\hline Due $^{*}$ & Topic & Prompt \\
\hline Day 1 & $\begin{array}{l}\text { History of the drug and its } \\
\text { development }\end{array}$ & $\begin{array}{l}\text { Look up the background of your } \\
\text { drug: What is the history of } \\
\text { your drug and its development? }\end{array}$ \\
\hline Day 2 & $\begin{array}{l}\text { Physicochemical properties of } \\
\text { the drug and effect on } \\
\text { pharmacokinetics }\end{array}$ & $\begin{array}{l}\text { Look up the structure of your } \\
\text { drug: How does its chemical } \\
\text { structure affect its } \\
\text { pharmacokinetics, and how } \\
\text { does this affect how it is } \\
\text { administered to patients? }\end{array}$ \\
\hline Day 3 & $\begin{array}{l}\text { Pharmacology of the drug and } \\
\text { place in pathway }\end{array}$ & $\begin{array}{l}\text { Look up the protein that your } \\
\text { drug targets: Where is the } \\
\text { target, what does it do to its } \\
\text { target, and how does this affect } \\
\text { the pathway and course of the } \\
\text { disease? }\end{array}$ \\
\hline Day 4 & $\begin{array}{l}\text { Place in therapy of the drug, } \\
\text { comparison to other } \\
\text { medications }\end{array}$ & $\begin{array}{l}\text { Look up your drug in the } \\
\text { American Diabetes Association } \\
\text { treatment guidelines: What is } \\
\text { its place therapy? What } \\
\text { advantages or disadvantages } \\
\text { does it have relative to other } \\
\text { medications? }\end{array}$ \\
\hline
\end{tabular}

* A slide was due each day, with the request that the slide should answer the main prompt (italicised)

The details of the projects are shown in Tables II and III. Project 1 focused on the pharmacology of four anti-diabetes agents (glipizide, alogliptin, repaglinide, 
canagliflozin), with one assigned to each group. Assignments were due on Day 1 to 4 , and were written in response to the prompts shown in Table II and in parallel with the lecture material in Table I. Project 2 focused on potential DDIs described in four case reports (again with one assigned to each group). Thus, the design of this project (Table III) provided an opportunity for students to gain familiarity with reading multiple types of literature, including case reports, clinical trials, and in vitro studies. To promote higher order thinking and integration of material, continuous revision of a draft of a document for presentation on Day 10 was required (Table I). Each day, students submitted their work at the end of the student group work period (Figure A). Faculty and facilitators provided daily feedback to each group as the document was developed.

Table III: Design of project 2 - Scientific explanation and clinical management of drug-drug interactions based on an assigned case report

\begin{tabular}{|c|c|c|}
\hline Due $^{*}$ & Scientific Task $^{\dagger}$ & Clinical Task \\
\hline Day 6 & $\begin{array}{l}\text { Find data for physicochemical } \\
\text { properties and } \\
\text { pharmacokinetics: } \mathrm{pK}_{\mathrm{a}} \\
\text { solubility, } \mathrm{C}_{\max }, \mathrm{T}_{\max }, \mathrm{T}_{1 / 2,} \text { AUC, } \\
\text { dose, population. \% protein } \\
\text { bound, bioavailability }\end{array}$ & $\begin{array}{l}\text { Check to see if the DDI has been } \\
\text { previously documented using } \\
\text { drug information resources (e.g. } \\
\text { Micromedex), also noting } \\
\text { incidence and severity if } \\
\text { reported. }\end{array}$ \\
\hline Day 7 & $\begin{array}{l}\text { Find data for drug binding to } \\
\text { uptake and efflux transporters: } \\
\text { substrate, inhibitor, inducer; } \\
\mathrm{K}_{\mathrm{m}}, \mathrm{V}_{\max }, \mathrm{K}_{\mathrm{D}}, \mathrm{IC}_{50}\end{array}$ & $\begin{array}{l}\text { Perform the Naranjo and } \\
\text { Liverpool algorithms to assess } \\
\text { the ADR using the information } \\
\text { available in the case report. }\end{array}$ \\
\hline Day 8 & $\begin{array}{l}\text { Find data for drug metabolism } \\
\text { with CYPs and other enzyme: } \\
\text { substrate, inhibitor inducer; } \\
\mathrm{K}_{\mathrm{m}}, \mathrm{V}_{\max }, \mathrm{K}_{\mathrm{D}}, \mathrm{IC}_{50}\end{array}$ & $\begin{array}{l}\text { Find information on severity of } \\
\text { effects and appropriate medical } \\
\text { management. } \\
\text { Research if similar incidents } \\
\text { have been reported for the } \\
\text { specific drugs or the drug } \\
\text { classes. Consider alternatives. }\end{array}$ \\
\hline Day $9^{\ddagger}$ & $\begin{array}{l}\text { Determine if the drugs interact } \\
\text { with the same CYP or the same } \\
\text { transporter } \\
\text { Determine if the plasma } \\
\text { concentrations support the } \\
\text { importance of a particular } \\
\text { protein in the DDI (in vitro-in } \\
\text { vivo correlation) } \\
\text { Justify your level of confidence } \\
\text { in assigning a particular } \\
\text { mechanism for the DDI }\end{array}$ & $\begin{array}{l}\text { Develop recommendations for } \\
\text { managing the DDI, both for the } \\
\text { specific patient in the case } \\
\text { report, and patients in general. } \\
\text { Recommend one of the } \\
\text { following: change the dose of } \\
\text { one or both agents, discontinue } \\
\text { one or both agents, replace one } \\
\text { or both agents, add an } \\
\text { additional agent to manage } \\
\text { effects, or monitor without } \\
\text { changes. }\end{array}$ \\
\hline
\end{tabular}

Day 10 ? Presentation of case report summary, $\mathrm{ADME}^{\S}$ properties of the two drugs, assessment of DDI (scientific mechanism and clinical relevance), and clinical recommendation for future treatment of the patient

\footnotetext{
"Material was submitted each day, and facilitators discussed the progress of the project and provided feedback on slides being developed for the group presentation on day 10 . ${ }^{+}$For both drugs

${ }^{\ddagger}$ Broad issues considered in each group based on earlier findings

" Finalisation of PowerPoint presentation to include scientific and clinical conclusions $\S$ ADME: absorption, distribution, metabolism, elimination
}

\section{Course delivery and active learning}

Almost all material was taught synchronously via Zoom, with brief pre-reading or pre-recorded lectures for a few sessions. The key principle in delivering the material was that short lectures of 10 to 15 minutes would be followed by facilitated group discussions (in Zoom breakout rooms) for another 10 to 15 minutes, with this repeated three times in each clinical or science session. The final hour of each day was spent discussing lecture material or project work in the breakout rooms.

\section{Learning management system}

Blackboard (Al Meajel \& Sharadgah, 2017; Alokluk, 2018) was used as the platform for dissemination of course material, upload, evaluation and feedback on assignments, and as a basis for establishing and launching Zoom meetings. These sessions were supported by an assigned meeting manager (one of the facilitators) each day. All students were provided with a USC e-mail address that, in principle, permitted them to have all rights to University content. Registering the participants with USC ID numbers also alleviated security concerns with software use.

\section{Evaluation of the course}

\section{Course implementation}

A total of 19 students from three universities in South Korea, Taiwan and Saudi Arabia enrolled in the course. All of the students were in undergraduate pharmacy programmes, at levels ranging from second year to fifth year. Students were nominated for participation in the course by their respective faculties. All had previous instruction in English and language skills were a minimal barrier to communication in the course. This was a prerequisite for enrolment in the course (USC ISSP, 2020). The students were assigned to four groups (three with five students and one with four) that were unchanged over the two weeks of the course. Two of the groups had students from all three countries and the other two had students from two countries. This assignment strategy was deliberate to encourage international exchange among the students with English as the common language.

Each teaching day (Table I), the course started at 6p.m. Pacific Daylight Time and formally ended at 9p.m. On most days, all groups then remained in breakout rooms with the group facilitator for up to another hour to work on project requirements. Course faculty moved around these rooms to listen to the discussion and provide advice 
as required. At least one course faculty was also available prior to class to address any remaining questions or technical concerns. Faculty and facilitators also held a pre-session meeting on most days to review progress and plan for the upcoming session (Figure A).

\section{Project work}

The central elements of Week 1 and 2 were the group-based projects (Tables II and III). The groups completed these projects partly during the online session with help from a facilitator, and then while working alone. The final PowerPoint documents for Project 1 are shown on the ISSP website (USC ISSP, 2020). The objectives for completion of Project 1 (Table II) were set at the lower levels of the revised Bloom's Taxonomy for cognition (Anderson \& Krathwohl, 2001; Armstrong, 2020), based on listing and describing data (Bloom's level 1, remembering), and then discussing the data (level 2, understanding) as part of the $Q$ \& $A$ session on Day 5 (Table I). The documents produced by the groups reflect a requirement for data collection through literature searching and an understanding of the collected data. This also allowed each group to establish a working model that they could carry forward into the more difficult challenge in Project 2.

Project 2 (Table III) was more challenging in that it required data collection and analysis (Day 6 to 8) followed by integration of these data to answer questions about a DDI case report. These skills are at higher Bloom's levels: level 3 (applying knowledge), level 4 (analysing data), and level 5 (evaluating data). Armstrong (2020) provides a detailed explanation and comparison of the original and revised Bloom's taxonomies. Completion of Project 2 was supported by background lectures and facilitation of group discussions. The initial scientific steps (Table III) were to collect qualitative evidence and numerical data (from the literature or from ADMET Predictor software) for the interactions of the potential victim and perpetrator drugs with proteins (metabolising enzymes and transporters) through which a DDI might occur. In parallel, the initial clinical components (Table III) included understanding the patient background, dosing regimens, and the symptoms of the apparent DDI. The Naranjo algorithm (Naranjo et al., 1981) and Liverpool Adverse Drug Reaction Causality Assessment Tool (Gallagher et al., 2011) for adverse drug reactions were used to determine the probability of a DDI being present.

This activity was followed by development of a hypothesis of the source of the DDI (following that given in the case report, if provided, and considering other possibilities).
The subsequent scientific task was to examine the collected data to support or refute this hypothesis, based on in vitro IC50, $\mathrm{Km}$ and Vmax values, plasma levels, and elimination routes of the drugs. Finally, the clinical management of the potential DDI was explored, with a recommendation on potential adjustments to doses or agents (Table III).

\section{Assessment of student learning}

Twelve questions selected by faculty from those written by the student groups ( 3 per group) and eight questions written by faculty were used on Day 5 to evaluate student learning for the first week. These questions were in a multiple choice format and included interpretation of scientific data and patient cases. The questions can be viewed on the ISSP website (USC ISSP, 2020). This session was run using Kahoot! (Licorish et al., 2018; Wang \& Tahir, 2020) and made into an informal but serious competition among the groups. Each group submitted one answer on Kahoot!. After every question, one student from the group that had written the question explained the reason for the correct answer and explained why the distractor answers were incorrect. Faculty provided these explanations for faculty questions. The average score for the four groups was $82 \%$ (range $77-91 \%$ ), which indicated a good level of understanding.

The group talks on Day 10 were more formal, but to provide some humour and community-building, a spinning wheel (Wheelofnames, 2020) was introduced to select which group would talk first, second, etc. Each student in a group talked for three to five minutes based on a single group PowerPoint file, which was controlled by a group member sharing their screen. The talks were not formally graded, but each group received questions from faculty on the content. There was a consensus among the faculty that all four groups had reached a remarkably high level in a short period of time. This is evident from the level of detail in the PowerPoint presentations (USC ISSP, 2020b). The high Bloom's level activities in Project 2 were challenging for the students and required considerable facilitation, but the presentations of the project on Day 10 indicated that students understood the data they had gathered and could apply this information to clinical decision-making.

\section{Post-course survey}

An anonymous survey was sent to the students a few days after the end of the course and was completed within one week. Responses were obtained from 15 students (79\%). The results are shown in Table IV. The 
Table IV: Results from a survey completed in the week following the course

\begin{tabular}{|c|c|c|c|c|c|c|c|c|}
\hline Category* & Question & $\mathbf{S A}^{+}$ & A & $\mathbf{N}$ & D & SD & \% Question ${ }^{\ddagger}$ & \% Category \\
\hline \multirow[t]{4}{*}{ Organisation } & 1. The course was well organised ${ }^{\S}$ & 10 & 4 & & & & $94.3 \%$ & \\
\hline & 2. The science and clinical sessions were well integrated ${ }^{\S}$ & 11 & 3 & & & & $95.7 \%$ & \\
\hline & 3. Virtual classroom sessions were engaging & 7 & 7 & 1 & & & $88.0 \%$ & \\
\hline & 4. Blackboard, the online learning system, supported my learning. & 11 & 3 & 1 & & & $93.3 \%$ & $92.8 \%$ \\
\hline \multirow[t]{4}{*}{ Assignments } & 5. The assignments were appropriately challenging & 9 & 4 & 1 & 1 & & $88.0 \%$ & \\
\hline & 6. I had sufficient time to work on the assignments & 7 & 4 & 3 & 1 & & $82.7 \%$ & \\
\hline & 7. The instructions provided were clear & 9 & 5 & 1 & & & $90.7 \%$ & \\
\hline & 8. I had sufficient support from my small group facilitator & 12 & 1 & 2 & & & $93.3 \%$ & $88.7 \%$ \\
\hline \multirow[t]{4}{*}{ Project 1} & 9. Preparing PowerPoint slides with my team facilitated my learning & 8 & 7 & & & & $90.7 \%$ & \\
\hline & $\begin{array}{l}\text { 10. Preparing questions and answers for the competition facilitated } \\
\text { my learning }\end{array}$ & 10 & 5 & & & & $93.3 \%$ & \\
\hline & $\begin{array}{l}\text { 11. The final team competition question and answer session } \\
\text { (Kahoot!) helped me to assess what I had learned }\end{array}$ & 10 & 4 & 1 & & & $92.0 \%$ & \\
\hline & $\begin{array}{l}\text { 12. I enjoyed the final team competition question and answer } \\
\text { session (Kahoot!) }\end{array}$ & 12 & 2 & 1 & & & $94.7 \%$ & $92.7 \%$ \\
\hline \multirow[t]{4}{*}{ Project 2} & $\begin{array}{l}\text { 13. Interpreting the assigned case report increased my ability to } \\
\text { analyse drug-drug interactions }{ }^{\S}\end{array}$ & 12 & 2 & & & & $97.1 \%$ & \\
\hline & $\begin{array}{l}\text { 14. Use of ADMET Predictor and GastroPlus increased my ability to } \\
\text { analyse drug-drug interactions }\end{array}$ & 11 & 2 & 2 & & & $92.0 \%$ & \\
\hline & $\begin{array}{l}\text { 15. Use of algorithms and drug information resources increased my } \\
\text { ability to analyse drug-drug interactions }\end{array}$ & 11 & 3 & 1 & & & $93.3 \%$ & \\
\hline & $\begin{array}{l}\text { 16. Creating our group presentation increased my confidence in } \\
\text { preparing a professional presentation }\end{array}$ & 10 & 3 & 2 & & & $90.7 \%$ & $93.2 \%$ \\
\hline \multirow[t]{4}{*}{ Group Work } & 17. Enhanced my learning & 10 & 3 & 1 & 1 & & $89.3 \%$ & \\
\hline & 18. Helped me to practice speaking English & 7 & 6 & 1 & 1 & & $85.3 \%$ & \\
\hline & 19. Was fun & 9 & 4 & 1 & & 1 & $86.7 \%$ & \\
\hline & 20. Helped me to learn about working in teams with colleagues & 10 & 3 & 1 & & 1 & $88.0 \%$ & $87.3 \%$ \\
\hline \multirow[t]{2}{*}{ Overall } & 21. This programme was of value to my education. & 13 & 2 & & & & $97.3 \%$ & \\
\hline & 22. I would recommend this program to my friends. & 12 & 3 & & & & $96.0 \%$ & $96.7 \%$ \\
\hline
\end{tabular}

"Six categories were surveyed, with four questions each except for the Overall category

${ }^{\dagger} \mathrm{SA}=$ strongly agree, $\mathrm{A}=$ agree, $\mathrm{N}=$ neutral, $\mathrm{D}=$ disagree, $\mathrm{SD}=$ strongly disagree

${ }^{\ddagger}$ Calculated as a percentage for each question based on $S A=5, A=4, N=3, D=2, S=1$

"Average for the category

${ }^{\S}$ Only 14 responses were obtained for this question

questions were divided into six categories of four questions each, except for the overall category, which only had two questions. Answers to questions were scored on a 5-point Likert scale, as explained in the footnote to Table IV. The students were satisfied with the overall organisation of the course (Q1), but with some concern over engagement in the virtual sessions (Q3), which is a common problem with an online course. Assignments were perceived to have been clearly described (Q7) and facilitated (Q8), but with insufficient time for completion (Q6), which may have made them challenging for some students (Q5). A lot of information was included for a two-week course, and so these results are satisfactory. Project 1 (Q9-12) was generally well received, with a particularly good response to the Kahoot! assessment at the end of Week 1 . The considerably more challenging Project 2 (Q13-16) was equally well received overall and for the literature (Q13), science (Q14) and clinical (Q15) material. The lowest scores in the survey were in the Group Work category (Q17-20). These results may be due to the variation in undergraduate level among the students, which resulted in groups in which some students were more advanced. Also, the groups were transnational and the students had only a short time to establish relationships online. The scores for the group experience

should be viewed in this context. Finally, the high scores for the Overall category (Q21-22) vindicated the decision to offer the course. These results may be skewed by non-responder bias, but the findings were in line with the instructors' perceptions and those of faculty from the partner universities expressed in a post-course debrief. 


\section{Discussion}

The COVID-19 pandemic has made online education a necessity for faculty and students alike (Lederman, 2020). In this context, the decision to develop an online summer programme was straightforward, and was partly viewed as an opportunity to maintain contacts and distract from the crisis (Holcomb et al., 2020). At the same time, there was a concern that challenges in the online environment (Kebritchi et al., 2017) might have an impact on the ability to deliver the course and hinder student learning. These concerns were not warranted based on the positive feedback from the attendees and the work produced by the students. In the following paragraphs, the reasons underlying the successful implementation of the course are discussed. Most of these are applicable to any online setting, but some may apply specifically to an international setting.

In their extensive review of online teaching, Ní Shé et al. (2019) produced an excellent summary of the characteristics of this activity. In this review, the modern roles of online educators were concluded to be life skills promotion, design, facilitation, content expertise, and personal interaction, and the features of effective online teaching were grouped into three key elements of supporting students (affirmation), teaching presence (management), and cognitive presence (content). These are particularly useful items to keep in mind in online teaching. Careful design of the current summer course provided a foundation for delivery of material by content experts (faculty) and well-informed group facilitators. This established a personal feel to the course through broad availability and accessibility of faculty and through integration of a facilitator into each group. Students were also provided with daily constructive feedback to support their work. This is not different to an on-campus class in many respects, but it may be even more important online to provide this feedback with great clarity. As pointed out by Ní Shé et al. (2019), such course management is critical. The relative lack of visual cues makes it particularly important to define what is expected on a given day and to repeat this several times

The course was also facilitated by recent improvements in communication technology, as reflected in the Zoom platform. In the authors' previous study of online pharmacy education (El Magboub et al., 2016) (ironically, to examine this approach as a means of moving online in the event of a crisis and never imagined the time that this would become a reality), technology was perceived by students to be a major barrier. In contrast, in the current course, Zoom provided the means for effective facilitation through utilisation of breakout rooms, with only a few problems with connectivity. This is remarkable given the geographic distribution of the faculty, facilitators and students, in addition to the limited time for definition of hardware requirements. This shows the potential for such courses to be held with minimal technical planning or support.

The First International Congress on Clinical Pharmacy Education was held in 1976 (Ray, 1977). Subsequently, the Globalisation of Pharmaceutics Education Network (GPEN, 2020), the American Association of Colleges of Pharmacy (Audus et al., 2010) and the International Pharmaceutical Federation (FIP, 2020) have all played major roles in internationalisation of pharmacy education (Alsharif et al., 2017). However, much of this has occurred at the Ph.D. (GPEN, 2020) and Pharm.D. experiential (Cisneros et al., 2013; Al-Dahir et al., 2017) levels, with less attention paid to undergraduate pharmacy students. The current course showed the value of engaging these students in pharmacology and clinical pharmacy at an early stage of their education. Focusing on a common disease state (diabetes) that is a growing concern worldwide (International Diabetes Federation, 2020) and DDIs as an important aspect of pharmacy education permitted strong integration of science and clinical knowledge.

\section{Future Plans}

The successful implementation of the online course indicates the potential for similar international undergraduate teaching beyond the current COVID-19 pandemic. The online experience does not replace a residential course, and a return to this activity is hoped for in 2021. However, such courses are expensive and may not be financially accessible to all students (Whatley, 2017). There are barriers to collaboration between students from different countries, even for students in relatively closely related countries such as the United States and Canada (McCollum et al., 2019). Such difficulties included different teaching styles and social interaction. Similarly, there was some evidence of difficulty with intra-group communication among the students in the course. This might be improved by some early online social activity to allow students to get to know each other better.

Despite these limitations, a future is envisioned in which online international teaching of undergraduate pharmacy is routine. While the online design of the course described here was forced upon us by the COVID-19 pandemic, the experience showed that the same approach can be used 
under normal circumstances. The course design has sufficient flexibility to develop future offerings that run over periods of two weeks to several months, and longer versions of the course for domestic and international audiences are currently being considered. This kind of online course can have major innovative effects on pharmacy education, scientific discovery and clinical practice through sharing of ideas on an international level.

\section{Acknowledgements}

We are particularly grateful to the students for their many efforts in the course; to the faculty of the partner universities for their advice on planning the course; and to Dr. Kevin Forrester (USC School of Pharmacy) and Dr. Hovhannes 'Hovik' Gukasyan (Abbvie) for their contributions as guest speakers. This paper is dedicated to the memory of the late Dr. Michael Z. Wincor. Prof. Wincor was a great advocate for international undergraduate pharmacy education at the USC School of Pharmacy. We remain in his debt for his initial establishment and subsequent guidance of the international summer programme for many years.

\section{References}

Al-Dahir, S., Alsharif, N.Z., Gleason, S.E., Tofade, T., Flores, E.K., Katz, M., \& Dornblaser, E.K. (2017). Current practices in hosting non-US pharmacy students at US pharmacy schools in experiential clerkships. American Journal of Pharmaceutical Education, 81(9), 6004. https://doi.org/10.5688/ajpe6004

Al Meajel, T.M., \& Sharadgah, T.A. (2017). Barriers to using the Blackboard system in teaching and learning: faculty perceptions. Technology, Knowledge and Learning, 23, 351-366. https://doi. org/10.1007/s10758-017-9323-2

Alokluk, J.A. (2018) The effectiveness of Blackboard system, uses and limitations in information management. Intelligent Information Management, 10(6), 133-149. https://doi.org/10. 4236/iim.2018.106012

Alsharif, N.Z. (2017). Purposeful global engagement in pharmacy education. American Journal of Pharmaceutical Education, 81(10), 6882. https://doi.org/10.5688/ajpe6882

Anderson, L.W., \& Krathwohl, D.R. (2001). A taxonomy for learning, teaching, and assessing: a revision of Bloom's taxonomy of educational objectives. New York: Longman

Armstrong, P. (2020) Bloom's Taxonomy. Available at: https://cft. vanderbilt.edu/guides-sub-pages/blooms-taxonomy/

Audus, K.L., Moreton, J.E., Normann, S.A., Sands, C.D., Seaba, H.H., Wincor, M.Z., Sagraves, R., \& Miller, K.W. (2010). Going global: the report of the 2009-2010 research and graduate affairs committee. American Journal of Pharmaceutical Education, 74(10), S8. https:// doi.org/10.5688/aj7410S8
Boglou, P., Steiropoulos, P., Papanas, N., \& Bouros, D. (2013), Hypoglycaemia due to interaction of glimepiride with isoniazid in a patient with type 2 diabetes mellitus. BMJ Case Reports, 2013, bcr2012008528. https://doi.org/10.1136/bcr-2012-008528

Chan, J.C.M., Ng, M.-H., Wong, R.S.M., \& Tomlinson, B. (2019). A case of simvastatin-induced myopathy with SLCO1B1 genetic predisposition and co-ingestion of linagliptin and Stevia rebaudiana. Journal of Clinical Pharmacy and Therapeutics, 44(3), 381-383. https://doi.org/10.1111/icpt.12805

Chochol, M.D., Kataria, L., O'Rourke, M.C., \& Lamotte, G. (2019). Clozapine-associated myoclonus and stuttering secondary to smoking cessation and drug interaction. Journal of Clinical Psychopharmacology, 39(3), 275-277. https://doi.org/10.1097/ JCP.0000000000001032

Cisneros, R.M., Jawaid, S.P., Kendall, D.A., McPherson, C.E., Mu, K., Weston, G.S., \& Roberts, K.B. (2013). International practice experiences in pharmacy education. American Journal of Pharmaceutical Education, 77(9), 188. https://doi.org/10.5688/ ajpe779188

De Sandes-Guimaraes, L.V., Ribeiro, A.T.V.B., Axel-Berg, J.H., de Rosso Manços, G., \& Plonski, G.A. (2019). International student mobility programs change student entrepreneurial perceptions. Journal of Studies in International Education, 24, 249-268. https:/ Ldoi.org/10.1177/1028315319842345

El-Magboub, A., Haworth, I.S., Sutch, B.T., \& Romero, R.M. (2016). Evaluation of in-class and online discussion meetings in a biopharmaceutics problem-based learning class. Currents in Pharmacy Teaching and Learning, 8(6), 811-820. https://doi.org/ 10.1016/j.cptl.2016.08.021

FIP [International Pharmaceutical Federation]. (2020). Available at: https://www.fip.org/

Gallagher, R.M., Kirkham, J.J., Mason, J.R., Bird, K.A., Williamson, P.R., Nunn, A.J., Turner, M.A., Smyth, R.L., \& Pirmohamed, M. (2011) Development and inter-rater reliability of the Liverpool adverse drug reaction causality assessment tool. PloS One, 6, e28096. https://doi.org/10.1371/journal.pone.0028096

Giedt, T., Gokcek, G., \& Ghosh, J. (2015). International education in the 21st century: the importance of faculty in developing study abroad research opportunities. Frontiers: The Interdisciplinary Journal of Study Abroad, 26(1), 167-186. https://doi.org/10. 36366/frontiers.v26i1.365

GPEN [Globalisation of Pharmaceutics Education Network]. (2020). Available at: http://pharmchem.ku.edu/globalizationpharmaceutics-education-network-gpen

Holcomb, J., Jackson, J., Korstange, R., \& Hall J. (2020). Established online education is not immune to COVID-19: strategies for serving students during the COVID-19 pandemic. The Evolllution: A destiny solutions illumination. Available at: https://evolllution. com/attracting-students/customer service/established-online-ed ucation-is-not-immune-to-covid-19-strategies-for-serving-student s-during-the-covid-19-pandemic/

International Diabetes Federation (2020). Available at: https:/ Lwww.idf.org/aboutdiabetes/what-is-diabetes/facts-figures.html 
Kato, M., \& Suzuki, K. (2018). Effective or self-selective: random assignment demonstrates short-term study abroad effectively encourages further study abroad. Journal of Studies in International Education, 23(4), 411-428. https://doi.org/10.1177/ $\underline{1028315318803713}$

Kebritchi, M., Lipschuetz, A., \& Santiague, L. (2017). Issues and challenges for teaching successful online courses in higher education: a literature review. Journal of Educational Technology Systems, 46(1), 4-29. https://doi.org/10.1177/0047239516661713

Lederman, D. (2020) The shift to remote learning: the human element. Inside Higher Ed. Available at: https://www.inside highered.com/digital-learning/article/2020/03/25/how-shift-remo te-learning-might-affect-students-instructors-and

Licorish, S.A., Owen, H.E., Daniel, B., \& George, J.L. (2018). Students' perception of Kahoot!'s influence on teaching and learning. Research and Practice in Technology Enhanced Learning, 13, 9. https://doi.org/10.1186/s41039-018-0078-8

McCollum, B., Morsch, L., Shokoples, B., \& Skagen, D. (2019). Overcoming barriers for implementing international online collaborative assignments in chemistry. The Canadian Journal for the Scholarship of Teaching and Learning, 10(1), 6. https://doi.org/ 10.5206/cjsotl-rcacea.2019.1.8004

Naranjo, C.A., Busto, U., Sellers, E.M., Sandor, P, Ruiz, I., Roberts, E.A., Janecek, E., Domecq, C., \& Greenblatt, D.J. (1981). A method for estimating the probability of adverse drug reactions. Clinical Pharmacology and Therapeutics, 30(2), 239-245. https://doi.org/ 10.1038/clpt.1981.154

Ní Shé, C., Farrell, O., Brunton, J., Costello, E., Donlon, E., Trevaskis, S., \& Eccles, S. (2019). Teaching online is different: critical perspectives from the literature. Zenodo. http://doi.org/10.5281 Lzenodo.3479402

Patel, C., Thompson, C., Copley-Harris, M., \& Hattab, Y. (2019). Sitagliptin and simvastatin interaction causing rhabdomyolysis and AKI. Case Reports in Medicine, Article ID 2601537, https://doi.org/ $\underline{10.1155 / 2019 / 2601537}$

Petzold, K. (2017). Studying abroad as a sorting criterion in the recruitment process: a field experiment among German employers. Journal of Studies in International Education, 21(5), 412-430. https://doi.org/10.1177/1028315317697543

Ray, M.D. (1977). Proceedings of the first international congress on clinical pharmacy education. American Journal of Hospital Pharmacy, 34, 519. https://doi.org/10.1093/ajhp/34.5.519a

Romero, R.M., Bolger, M.B., Morningstar-Kywi, N., \& Haworth, I.S. (2020). Teaching of biopharmaceutics in a drug design course: use of GastroPlus as educational software. Journal of Chemical Education, 97(8), 2212-2220. https://doi.org/10.1021/acs.jchemed .0c00401

Romero, R.M., Eriksen, S.P., \& Haworth, I.S. (2010). Quantitative assessment of assisted problem-based learning in a pharmaceutics course. American Journal of Pharmaceutical Education, 74(4), 66 https://doi.org/10.5688/aj740466

Ruth, A., Brewis, A., Blasco, D., \& Wutich, A. (2018). Long-term benefits of short-term research-integrated study abroad. Journal of Studies in International Education, 23(2), 265-280. https://doi. org/10.1177/1028315318786448
Simulations Plus (2020a). Science + Software $=$ Success. Admet Predictor. Available at: https://www.simulations-plus.com/ software/admetpredictor/

Simulations Plus (2020b). Science + Software $=$ Success. GastroPlus. Available at: https://www.simulations-plus.com/ software/gastroplus/

Sutch, B.T., Romero, R.M., Neamati, N., \& Haworth, I.S. (2011). Integrated teaching of structure-based drug design and biopharmaceutics: a computer-based approach. Journal of Chemical Education, 89(1), 45-51. https://doi.org/10.1021/ ed200151b

Take, H., \& Shoraku, A. (2017). Universities' expectations for study-abroad programs fostering internationalization: educational policies. Journal of Studies in International Education, 22(1), 37-52. https://doi.org/10.1177/1028315317724557

Toohey, D., McGill, T., \& Whitsed, C. (2017). Engaging academic staff in transnational teaching: the job satisfaction challenge. Journal of Studies in International Education, 21(4), 333-348. https://doi.org/10.1177/1028315317697523

USC ISSP (2020). USC School of Pharmacy Presents: Virtual Immersion in clinical Pharmacy and Therapeutics Summer program. Available at: https://sites.usc.edu/international summerprogram/

Vanden Berg, T.M., \& Schwander, L. (2019). The long-term impact of a short-term study abroad program: perspectives on global citizenship. Journal of Education and Learning, 8(4), 18-31. https://doi.org/10.5539/jel.v8n4p18

Wang, A.I., \& Tahir, R. (2020). The effect of using Kahoot! for learning: a literature review. Computers \& Education, 149, 103818. https://doi.org/10.1016/i.compedu.2020.103818

Whatley, M. (2017). Financing study abroad: an exploration of the influence of financial factors on student study abroad patterns. Journal of Studies in International Education, 21(5), 431-449. https://doi.org/10.1177/1028315317697798 